\title{
Sesquiterpenoids and Artificial 19-Oxygenated Steroids from the Formosan Soft Coral Nephthea erecta
}

\author{
Shi-Yie Cheng, ${ }^{\dagger}$ Chang-Feng Dai, ${ }^{\ddagger}$ and Chang-Yih Duh ${ }^{* \dagger, \S}$ \\ Department of Marine Biotechnology and Resources, National Sun Yat-sen University, Kaohsiung 804, Taiwan, Republic of China, Institute of \\ Oceanography, National Taiwan University, Taipei, Taiwan, Republic of China, and Center of Asia-Pacific Marine Researches, National Sun \\ Yat-sen University, Kaohsiung, Taiwan, Republic of China
}

Received April 25, 2007

\begin{abstract}
Chemical investigations on the acetone and $\mathrm{MeOH}$ solubles of the soft coral Nephthea erecta have afforded five new sesquiterpenoids (1-5), one known sesquiterpene, kelsoene (6), and two known 19-oxygenated steroids (10 and $\mathbf{1 1})$. In addition, three unexpected artificial 19-oxygenated steroids (7-9) were obtained by letting $\mathbf{1 0}$ and $\mathbf{1 1}$ stand in $\mathrm{CDCl}_{3}$ for prolonged periods of time. The structures of 1-9 were elucidated by extensive spectroscopic analyses, and their cytotoxicity against selected cancer cells was measured in vitro.
\end{abstract}

The family Nephtheidae has been proved to be a rich source of bioactive compounds. ${ }^{1-9}$ The ongoing search for bioactive constituents prompted us to reinvestigate the secondary metabolites of the soft coral Nephthea erecta Kükenthal (Nephtheidae). ${ }^{9}$ Compounds 1-6, ${ }^{10,11,14-17} \mathbf{1 0},{ }^{12}$ and $\mathbf{1 1}^{13}$ were isolated from the soft coral $N$. erecta while 7-9 are artifacts obtained by allowing $\mathbf{1 0}$ and $\mathbf{1 1}$ to stand in $\mathrm{CDCl}_{3}$ for prolonged periods of time. Compound 7 was obtained from $\mathbf{1 0}$ by letting the latter stand in $\mathrm{CDCl}_{3}$ overnight. Compound $\mathbf{7}$ was subsequently converted to 8 after 7 days. In the same conditions, 11 was transformed into 9 in $\mathrm{CDCl}_{3}$ after a week through epoxylation (Scheme 1). However, no reactions occurred when 10 and 11 were treated in pyridine- $d_{5}$ for 2 months, implying $\mathbf{1 0}$ and $\mathbf{1 1}$ were stable under slightly basic solvent. In this article, we report the structure elucidation and the cytotoxicity of these metabolites.

\section{Results and Discussion}

Compound 1 was isolated as a colorless, viscous oil. HRESIMS of 1 exhibited a $[\mathrm{M}+\mathrm{Na}]^{+}$peak at $m / z, 275.1625$ and established a molecular formula of $\mathrm{C}_{15} \mathrm{H}_{24} \mathrm{O}_{3}$, implying four degrees of unsaturation. The ${ }^{1} \mathrm{H}$ NMR spectrum of $\mathbf{1}$ (Table 1) showed signals corresponding to an oxygenated methine proton $\left[\delta_{\mathrm{H}} 4.77(1 \mathrm{H}\right.$, ddd, $J=3.5,2.0,1.5 \mathrm{~Hz})]$, an olefinic proton $\left[\delta_{\mathrm{H}} 6.21(1 \mathrm{H}, \mathrm{d}, J=1.5\right.$ $\mathrm{Hz})]$, a secondary methyl $\left[\delta_{\mathrm{H}} 1.00(3 \mathrm{H}, \mathrm{d}, J=7.0 \mathrm{~Hz})\right]$, and three tertiary methyls $\left[\delta_{\mathrm{H}} 1.44(3 \mathrm{H}, \mathrm{s}) ; \delta_{\mathrm{H}} 1.47(3 \mathrm{H}, \mathrm{s}) ; \delta_{\mathrm{H}} 0.89(3 \mathrm{H}\right.$, $\mathrm{s})$, respectively. The ${ }^{13} \mathrm{C}$ NMR displayed 15 carbon resonances, and the DEPT spectrum (Table 1) was consistent with the presence of a methine $\left[\delta_{\mathrm{C}} 71.4(\mathrm{CH})\right]$, a quaternary carbon $\left[\delta_{\mathrm{C}} 81.5(\mathrm{qC})\right]$ bearing a peroxide ring, a quaternary carbon $\left[\delta_{\mathrm{C}} 70.7(\mathrm{qC})\right]$ bearing a hydroxyl, and trisubstituted olefinic carbons $\left[\delta_{\mathrm{C}} 124.2(\mathrm{CH})\right.$ and 149.5 (qC)], as well as four methyls, four methylenes, three methines, and four quaternary carbons. The above data of $\mathbf{1}$ were similar to those of $5 \alpha, 8 \alpha$-epidioxy-6-eudesmene, ${ }^{14}$ except for the presence of a tertiary hydroxyl at C-11. This was supported by the HMBC spectrum, which shows correlations from $\mathrm{H}_{3}-12$ and $\mathrm{H}_{3}-13$ to $\mathrm{C}-11$ (Figure 1). On the basis of the above evidence, the planar structure of $\mathbf{1}$ was unambiguously established. The computermodeled structure of $\mathbf{1}$ was generated by CS Chem 3D version 9.0 using MM2 force field calculations for energy minimization (Figure 2 ). The results were consistent with the stereochemistry of $\mathbf{1}$ as established by the NOESY experiments. The NOESY correlations

* To whom correspondence should be addressed. Tel: 886-7-5252000, ext. 5036. Fax: 886-7-5255020. E-mail: yihduh@nsysu.edu.tw.

National Sun Yat-sen University.

$\div$ National Taiwan University.

$\S$ Center of Asia-Pacific Marine Researches.

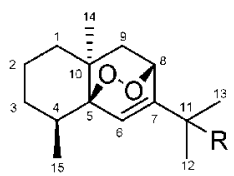

$1 \mathrm{R}=\mathrm{OH}$

$2 \mathrm{R}=\mathrm{OOH}$

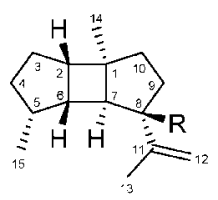

$4 \mathrm{R}=\mathrm{OH}$ $5 \mathrm{R}=\mathrm{OOH}$

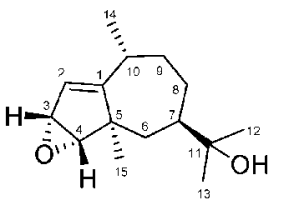

3

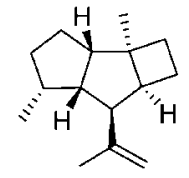

6

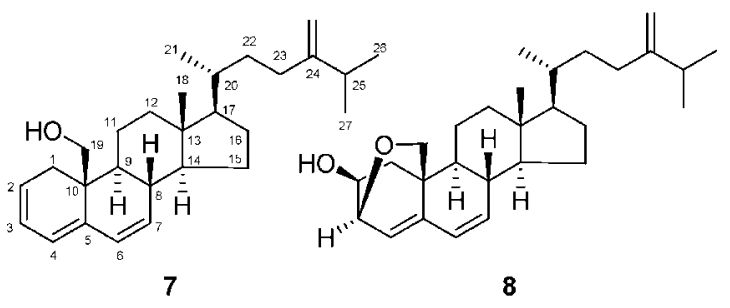

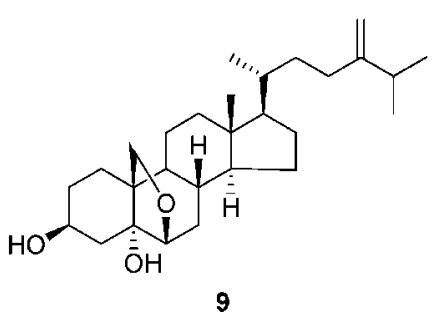

between $\mathrm{H}_{3}-14$ and all protons of $\mathrm{H}-1 \alpha, \mathrm{H}-4, \mathrm{H}-8$, and $\mathrm{H}-9 \alpha$ positioned all these protons on the same side of the molecule and revealed the $\beta$-orientation of $\mathrm{H}_{3}-15$. Therefore, the structure of $5 \beta, 8 \beta$-epidioxy-11-hydroxy-6-eudesmene was characterized as $\mathbf{1}$.

$5 \beta, 8 \beta$-Epidioxy-11-hydroperoxy-6-eudesmene (2) was isolated as a colorless, viscous oil, and its molecular formula was determined to be $\mathrm{C}_{15} \mathrm{H}_{24} \mathrm{O}_{4}$, as deduced from HRESIMS spectroscopic data. The ${ }^{1} \mathrm{H}$ NMR spectrum of 2 showed a signal at $\delta_{\mathrm{H}} 7.72(1 \mathrm{H}, \mathrm{br} \mathrm{s})$ that suggested the presence of a hydroperoxy group, while the hydroperoxyl could be located at $\mathrm{C}-11$, as a result of the HMBC correlations (Figure 1). The carbon signals of Me-12 and Me-13 of 1 were at a lower field when compared to $\mathbf{2}$, and the signal of $\mathrm{C}-11$ was shifted downfield $\left(\Delta \delta_{\mathrm{C}} 11.1 \mathrm{ppm}\right)$. The ${ }^{13} \mathrm{C} \mathrm{NMR}$ 
Scheme 1. Suggested Pathway for Conversion of $\mathbf{7}$ to $\mathbf{8}$ and $\mathbf{1 1}$ to $\mathbf{9}$

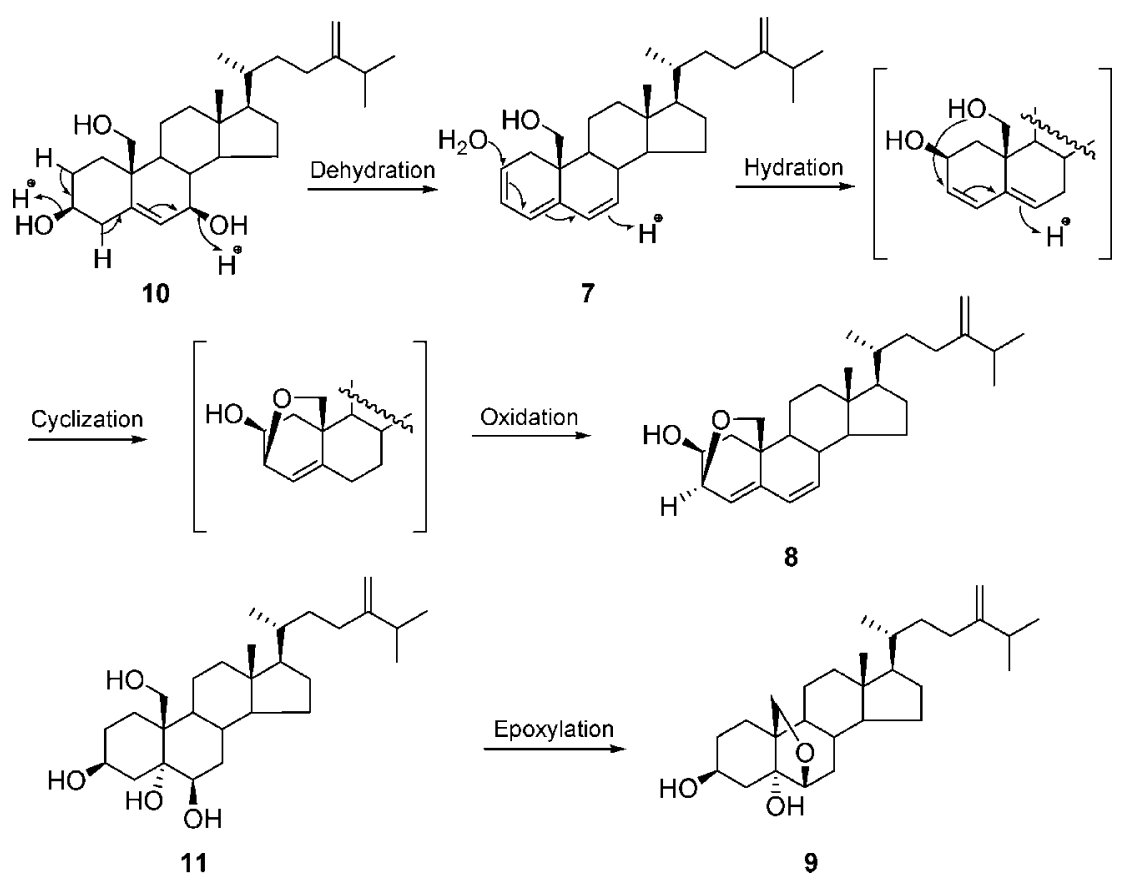

Table 1. ${ }^{1} \mathrm{H}$ and ${ }^{13} \mathrm{C}$ NMR Spectroscopic Data of Compounds 1-3

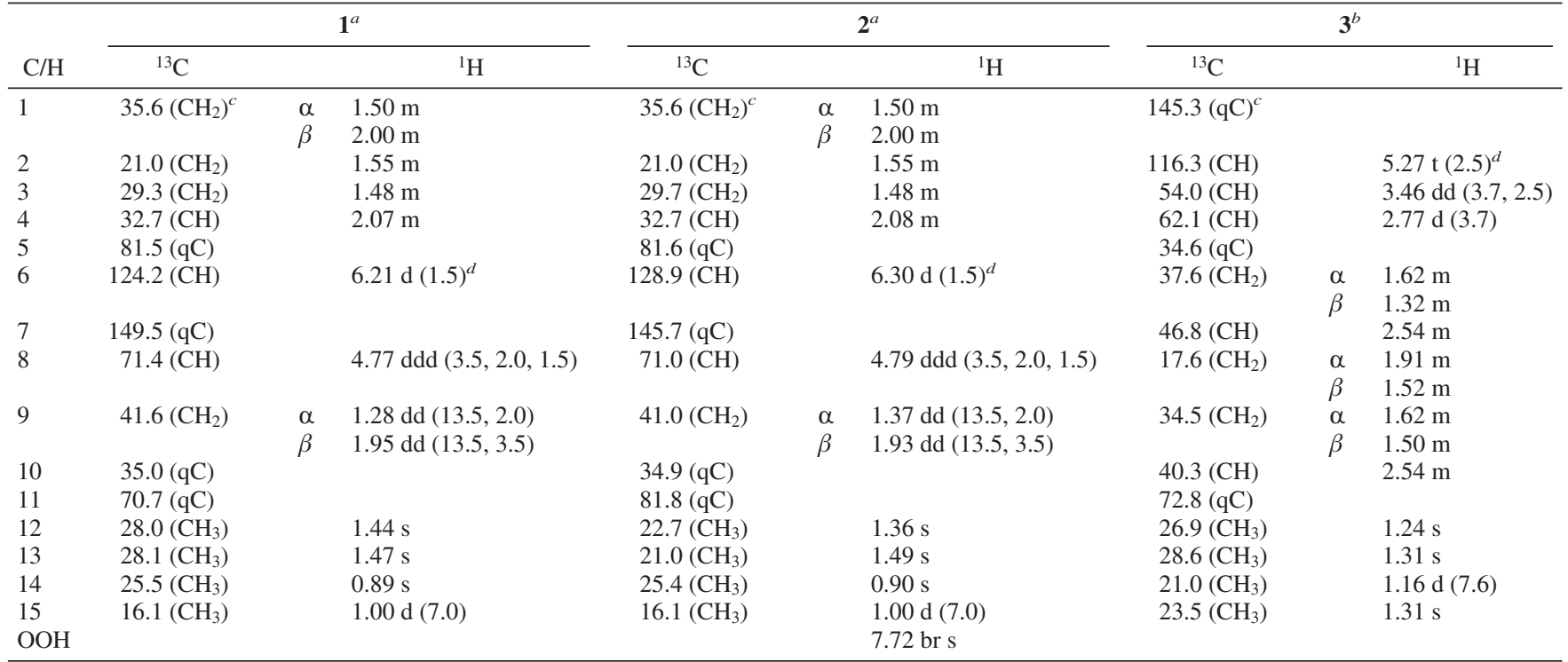

${ }^{a}$ Spectra were measured in $\mathrm{CDCl}_{3}\left({ }^{1} \mathrm{H}, 300 \mathrm{MHz}\right.$ and $\left.{ }^{13} \mathrm{C}, 75 \mathrm{MHz}\right) .{ }^{b}$ Spectra were measured in $\mathrm{CDCl}_{3}\left({ }^{1} \mathrm{H}, 500 \mathrm{MHz}\right.$ and $\left.{ }^{13} \mathrm{C}, 125 \mathrm{MHz}\right)$. ${ }^{c}$ Multiplicities are deduced by HSQC and DEPT experiments. ${ }^{d} J$ values (in $\mathrm{Hz}$ ) are in parentheses.

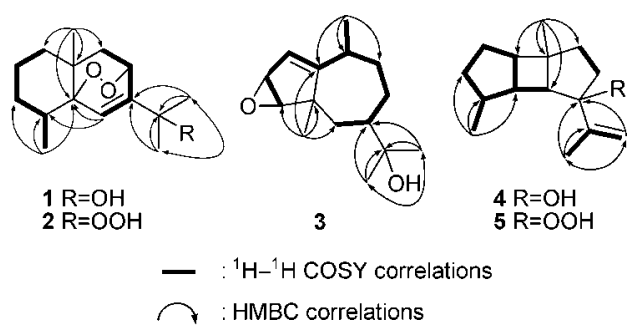

Figure 1. ${ }^{1} \mathrm{H}-{ }^{1} \mathrm{H}$ COSY and key HMBC correlation of $\mathbf{1 - 5}$.

spectroscopic data of $\mathbf{1}$ and $\mathbf{2}$ were in good accordance with those of compounds with a similar side chain with a hydroxyl or a hydroperoxyl. ${ }^{16,17}$ Consequently, the structure of 2 was deduced unambiguously.

Compound 3 was obtained as a colorless, viscous oil, which analyzed for the molecular formula $\mathrm{C}_{15} \mathrm{H}_{24} \mathrm{O}_{2}$ by HRESIMS coupled
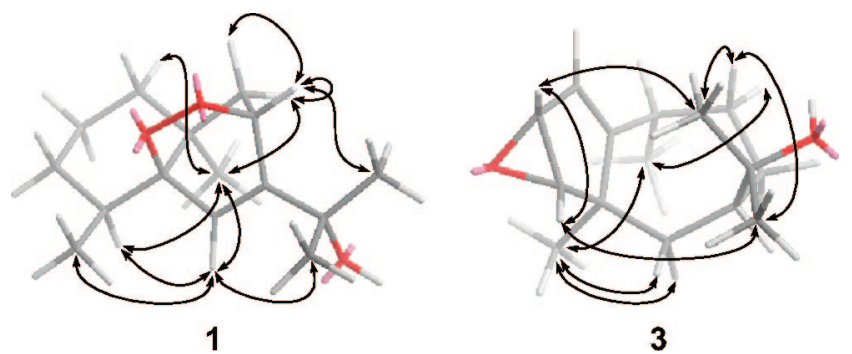

Figure 2. Selected NOSEY correlations of 1-3.

with the DEPT and ${ }^{13} \mathrm{C}$ NMR spectroscopic data (Table 1). A broad IR spectrum absorption at $3321 \mathrm{~cm}^{-1}$ indicated the presence of a hydroxy group. The ${ }^{1} \mathrm{H}$ and ${ }^{13} \mathrm{C}$ NMR spectra of $\mathbf{3}$ contained resonances for a trisubstituted double bond at C-1 and $\mathrm{C}-2\left[\delta_{\mathrm{H}} 5.27\right.$ (ddd, $J=3.5,2.0,1.5 \mathrm{~Hz}, 1 \mathrm{H}) ; \delta_{\mathrm{C}} 145.3(\mathrm{qC})$ and $\left.116.3(\mathrm{CH})\right]$ 


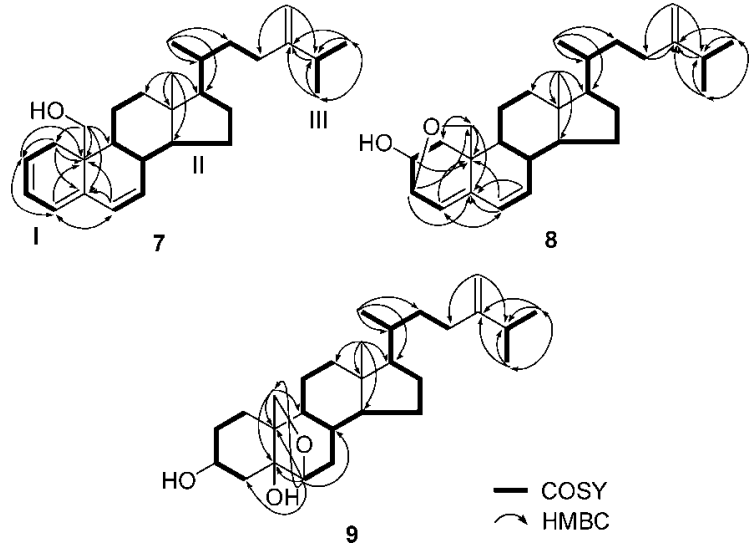

Figure 3. ${ }^{1} \mathrm{H}-{ }^{1} \mathrm{H}$ COSY and key HMBC correlations of 7-9.

and a disubstituted epoxide $\left[\delta_{\mathrm{H}} 3.46(\mathrm{dd}, J=3.7,2.5 \mathrm{~Hz}, 1 \mathrm{H})\right.$ and $2.77(\mathrm{~d}, J=3.7 \mathrm{~Hz}, 1 \mathrm{H}) ; \delta_{\mathrm{C}} 50.4(\mathrm{CH})$ and $\left.62.1(\mathrm{CH})\right]$ at $\mathrm{C}-3$ and $\mathrm{C}-4$. From the above evidences, 3 was suggested to be a tricyclic sesquiterpenoid. From the COSY spectrum of $\mathbf{3}$ (Figure 1), it was possible to establish that the proton sequence connects from $\mathrm{H}-2$ to $\mathrm{H}-4$ and from $\mathrm{H}_{2}-6$ to $\mathrm{H}_{3}-14$. The ${ }^{1} \mathrm{H}-{ }^{1} \mathrm{H}$ COSY correlations further observed between $\mathrm{H}-2$ and $\mathrm{H}-10$ showed further the allylic coupling of the above protons. The connectivities between $\mathrm{C}-1 / \mathrm{C}$ 5, C-4/C-5, and C-5/C-6 were confirmed by the HMBC correlations of $\mathrm{H}_{3}-15$ with $\mathrm{C}-1, \mathrm{C}-4, \mathrm{C}-5$, and $\mathrm{C}-6$. In addition, the HMBC correlations (Figure 1) from $\mathrm{H}_{3}-12$ and $\mathrm{H}_{3}-13$ to $\mathrm{C}-7$ and $\mathrm{C}-11$ proved the attachment of the isopropyl at $\mathrm{C}-7$. On the basis of this evidence, the planar structure of $\mathbf{3}$, possessing a pseudoguaiane ${ }^{15}$ skeleton, was unambiguously established. The relative configuration of $\mathbf{3}$ was determined through inspection of the NOESY spectrum as well as a computer-generated lower energy conformation using MM2 force field calculations (Figure 2). From the NOESY spectrum of $3, \mathrm{H}-9 \beta$ was found to show NOE correlations with both $\mathrm{H}_{3}-12$ and $\mathrm{H}_{3}-13$, and $\mathrm{H}-3$ exhibited NOE correlations with $\mathrm{H}-4$ and $\mathrm{H}_{3}-$ 12 , indicating the $\beta$-orientations of $\mathrm{H}-3$ and $\mathrm{H}-4$ and the $\beta$-orientation of the isopropanol group attached at $\mathrm{C}-11$. Furthermore, NOE correlations could be observed between $\mathrm{H}-9 \alpha$ and $\mathrm{H}_{3}-14, \mathrm{H}_{3}-14$, and $\mathrm{H}_{3}-15$. Therefore, $\mathrm{H}_{3}-14$ and $\mathrm{H}_{3}-15$ should be placed on the $\alpha$-face. From the aforementioned observations, 3 was formulated as $\quad\left(3 R^{*}, 4 S^{*}, 5 R^{*}, 7 R^{*}, 10 R^{*}\right)-3,4$-epoxy-11-hydroxy-1pseudoguaiene.

The molecular formula of $\mathbf{4}$ was assigned as $\mathrm{C}_{15} \mathrm{H}_{24} \mathrm{O}$, as derived from its HRESIMS and in agreement with the NMR data. By comparison of the ${ }^{13} \mathrm{C}$ NMR spectroscopic data of $\mathbf{4}$ with those of the known sesquiterpene prespatane, ${ }^{10,11}$ it was found that C-8 $\left(\delta_{\mathrm{C}}\right.$ $50.3 \mathrm{~d})$ in prespatane was converted to a tertiary hydroxyl $\left(\delta_{\mathrm{C}}\right.$ $87.8 \mathrm{~s})$ in $\mathbf{4}$, as also confirmed by the HMBC correlations $\left(\mathrm{H}_{3}-13\right.$ / $\mathrm{C}-8, \mathrm{C}-11$, and $\mathrm{C}-12$ ). Thus, the structure of $\mathbf{4}$ was established and named $8 \beta$-hydroxyprespatane. From the NOESY spectrum of $\mathbf{4}$, cross-peaks for the signals with $\mathrm{H}-2, \mathrm{H}-6$, and $\mathrm{H}-10 \beta(\delta 1.60)$ fixed the three rings in a stair or chair conformation, while the NOE interactions between $\mathrm{H}_{3}-15$ and all protons of $\mathrm{H}-7, \mathrm{H}_{3}-13$, and $\mathrm{H}_{3}-$ 14 , which in turn showed correlation with $\mathrm{H}-10 \alpha$, positioned the above protons on the same side of the molecule and revealed the $\beta$-orientation of the $8-\mathrm{OH}$.

HRESIMS of $8 \beta$-hydroperoxyprespatane (5), a colorless, viscous oil, established a molecular formula of $\mathrm{C}_{15} \mathrm{H}_{24} \mathrm{O}_{2}$. By comparison of the NMR spectroscopic data of $\mathbf{5}$ with those of $\mathbf{4}$, it was found that the ${ }^{1} \mathrm{H}$ and ${ }^{13} \mathrm{C}$ spectroscopic data of both compounds were nearly the same, except that the carbon shift of the tertiary hydroperoxyl at C-8 $\left(\delta_{\mathrm{C}} 100.2\right.$, s) of $\mathbf{5}$ was shifted downfield relative to the signal of C-8 $\left(\delta_{\mathrm{C}} 87.8, \mathrm{~s}\right)$ of $4 .^{16,17}$ Thus, the structure of 5 was established unambiguously.

Compound 7 was obtained from $\mathbf{1 0}$ by letting the latter stand in $\mathrm{CDCl}_{3}$ overnight. The ${ }^{1} \mathrm{H}$ and ${ }^{13} \mathrm{C}$ NMR spectroscopic data of 7 revealed the presence of a conjugated triene $\left(\delta_{\mathrm{C}} 126.4 \mathrm{CH}\right.$ and 124.2 $\mathrm{CH} ; \delta_{\mathrm{H}} 5.77 \mathrm{~m}$ and $5.92 \mathrm{~m} ; \delta_{\mathrm{C}} 121.7 \mathrm{CH}$ and $137.8 \mathrm{qC} ; \delta_{\mathrm{H}} 5.77 \mathrm{~d}$, $J=5.5 \mathrm{~Hz} ; \delta_{\mathrm{C}} 128.3 \mathrm{CH}$ and $132.5 \mathrm{CH} ; \delta_{\mathrm{H}} 6.05 \mathrm{dd}, J=9.6,2.4$ $\mathrm{Hz}$ and $5.68 \mathrm{~d}, J=9.6 \mathrm{~Hz}$ ) in rings $\mathrm{A}$ and $\mathrm{B}$. This was confirmed by $2 \mathrm{D}$ NMR spectroscopic analyses. Interpretation of the ${ }^{1} \mathrm{H}-{ }^{1} \mathrm{H}$ COSY spectrum led to partial structures I, II, and III (Figure 3). Partial structures I-III were connected by HMBC correlations.

24-Methylenecholesta-4,6-dien-3 $\beta, 19$-epoxy-2 $\beta$-ol (8) was obtained from 7 by letting the latter stand in $\mathrm{CDCl}_{3}$ for 1 week. The ${ }^{13} \mathrm{C}$ NMR and DEPT spectroscopic data of $\mathbf{8}$ showed signals for six olefin carbons, four methyl carbons, eight methylene carbons, eight methine carbons, and two quaternary carbons. The above functionalities account for three of the eight degrees of unsaturation, suggesting that $\mathbf{8}$ is a tetracyclic compound with a $3 \beta, 19$-epoxy moiety. The ${ }^{1} \mathrm{H}-{ }^{1} \mathrm{H}$ COSY spectrum correlations of $\mathbf{8}$ were similar

Table 2. ${ }^{1} \mathrm{H}$ and ${ }^{13} \mathrm{C}$ NMR Spectroscopic Data of Compounds 4 and 5

\begin{tabular}{|c|c|c|c|c|c|c|}
\hline \multirow[b]{2}{*}{$\mathrm{C} / \mathrm{H}$} & \multicolumn{3}{|c|}{$4^{a}$} & \multicolumn{3}{|c|}{$\mathbf{5}^{a}$} \\
\hline & ${ }^{13} \mathrm{C}$ & & ${ }^{1} \mathrm{H}$ & ${ }^{13} \mathrm{C}$ & & ${ }^{1} \mathrm{H}$ \\
\hline 1 & $42.3(\mathrm{qC})^{b}$ & & & $42.1(\mathrm{qC})^{b}$ & & \\
\hline 2 & $44.6(\mathrm{CH})$ & & $2.13 \mathrm{t}(7.0)^{c}$ & $45.1(\mathrm{CH})$ & & $2.18 \mathrm{~m}$ \\
\hline \multirow[t]{2}{*}{3} & $27.9\left(\mathrm{CH}_{2}\right)$ & $\alpha$ & $1.70 \mathrm{~m}$ & $27.9\left(\mathrm{CH}_{2}\right)$ & $\alpha$ & $1.70 \mathrm{~m}$ \\
\hline & & $\beta$ & $1.43 \mathrm{~m}$ & & $\beta$ & $1.45 \mathrm{~m}$ \\
\hline \multirow[t]{2}{*}{4} & $34.6\left(\mathrm{CH}_{2}\right)$ & $\alpha$ & $1.71 \mathrm{~m}$ & $34.6\left(\mathrm{CH}_{2}\right)$ & $\alpha$ & $1.72 \mathrm{~m}$ \\
\hline & & $\beta$ & $1.30 \mathrm{~m}$ & & $\beta$ & $1.29 \mathrm{~m}$ \\
\hline 5 & $37.1(\mathrm{CH})$ & & $1.82 \mathrm{~m}$ & $37.0(\mathrm{CH})$ & & $1.82 \mathrm{~m}$ \\
\hline 6 & $41.0(\mathrm{CH})$ & & $1.84 \mathrm{~m}$ & $41.4(\mathrm{CH})$ & & $1.95 \mathrm{~m}$ \\
\hline 7 & $50.4(\mathrm{CH})$ & & $1.80 \mathrm{~m}$ & $47.1(\mathrm{CH})$ & & $1.72 \mathrm{~m}$ \\
\hline 8 & $87.8(\mathrm{qC})$ & & & $100.2(\mathrm{qC})$ & & \\
\hline \multirow[t]{2}{*}{9} & $35.4\left(\mathrm{CH}_{2}\right)$ & $\alpha$ & $1.65 \mathrm{~m}$ & $29.2\left(\mathrm{CH}_{2}\right)$ & & $2.26 \mathrm{~m}$ \\
\hline & & $\beta$ & $2.40 \operatorname{td}(12.5,7.4)$ & & & \\
\hline \multirow[t]{2}{*}{10} & $39.9\left(\mathrm{CH}_{2}\right)$ & $\alpha$ & $1.85 \operatorname{td}(12.5,7.4)$ & $39.3\left(\mathrm{CH}_{2}\right)$ & $\alpha$ & $1.75 \mathrm{~m}$ \\
\hline & & $\beta$ & $1.60 \operatorname{td}(12.5,7.4)$ & & $\beta$ & $1.58 \mathrm{~m}$ \\
\hline 11 & $146.4(\mathrm{qC})$ & & & $143.3(\mathrm{qC})$ & & \\
\hline \multirow[t]{2}{*}{12} & $111.3\left(\mathrm{CH}_{2}\right)$ & & 4.87 br s & $114.7\left(\mathrm{CH}_{2}\right)$ & & 5.04 br s \\
\hline & & & 4.94 br s & & & 5.09 br s \\
\hline 13 & $19.3\left(\mathrm{CH}_{3}\right)$ & & 1.77 br s & $19.5\left(\mathrm{CH}_{3}\right)$ & & 1.75 br s \\
\hline 14 & $21.0\left(\mathrm{CH}_{3}\right)$ & & $1.04 \mathrm{~s}$ & $20.4\left(\mathrm{CH}_{3}\right)$ & & $0.97 \mathrm{~s}$ \\
\hline 15 & $14.5\left(\mathrm{CH}_{3}\right)$ & & $0.92 \mathrm{~d}(6.0)$ & $14.5\left(\mathrm{CH}_{3}\right)$ & & $0.90 \mathrm{~d}(6.3)^{c}$ \\
\hline $\mathrm{OOH}$ & & & & & & 7.71 br s \\
\hline
\end{tabular}

${ }^{a}$ Spectra were measured in $\mathrm{CDCl}_{3}\left({ }^{1} \mathrm{H}, 300 \mathrm{MHz}\right.$ and $\left.{ }^{13} \mathrm{C}, 75 \mathrm{MHz}\right) .{ }^{b}$ Multiplicities are deduced by $\mathrm{HSQC}$ and DEPT experiments. ${ }^{c} J$ values (in $\mathrm{Hz})$ are in parentheses. 
Table 3. ${ }^{1} \mathrm{H}$ and ${ }^{13} \mathrm{C}$ NMR Spectroscopic Data of Compounds 7-9

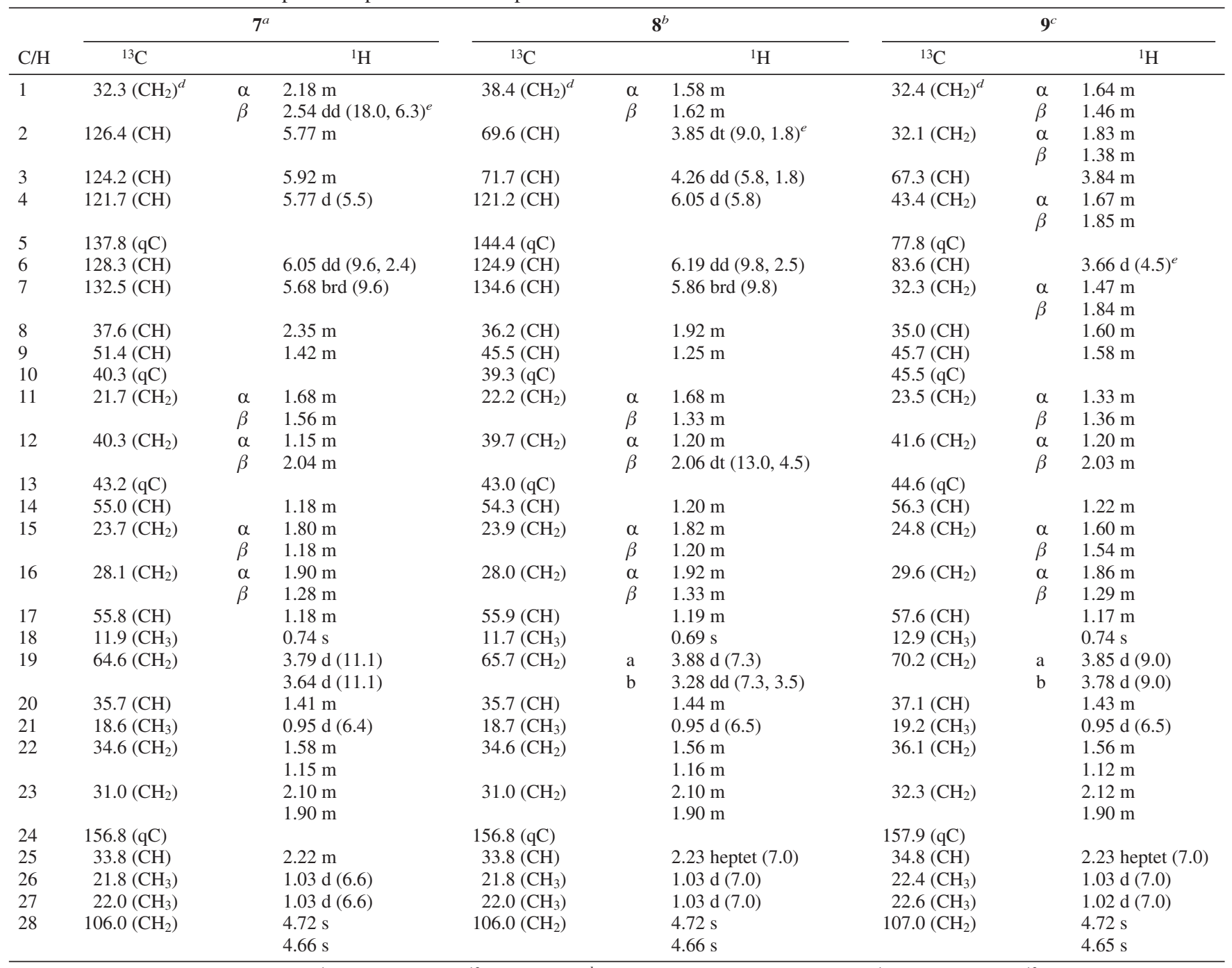

${ }^{a}$ Spectra were measured in $\mathrm{CDCl}_{3}\left({ }^{1} \mathrm{H}, 300 \mathrm{MHz}\right.$ and $\left.{ }^{13} \mathrm{C}, 75 \mathrm{MHz}\right) .{ }^{b}$ Spectra were measured in $\mathrm{CDCl}_{3}\left({ }^{1} \mathrm{H}, 500 \mathrm{MHz}\right.$ and $\left.{ }^{13} \mathrm{C}, 125 \mathrm{MHz}\right) .{ }^{c} \mathrm{Spectra}$ were measured in $\mathrm{CD}_{3} \mathrm{OD}\left({ }^{1} \mathrm{H}, 500 \mathrm{MHz}\right.$ and $\left.{ }^{13} \mathrm{C}, 125 \mathrm{MHz}\right) .{ }^{d}$ Multiplicities are deduced by HSQC and DEPT experiments. ${ }^{e} J$ values (in Hz) are in parentheses.

to those of 7. These data, together with the HMBC correlations (Figure 3), established the structure of $\mathbf{8}$.

HRESIMS of 24-methylenecholesta-6 $\beta, 19$-epoxy-3 $\beta, 5 \alpha$-diol (9) was obtained from 11 by letting the latter stand in $\mathrm{CDCl}_{3}$ for 1 week. By comparison of the NMR spectroscopic data (Table 3) of $\mathbf{9}$ with those of 11, ${ }^{13}$ it was found that hydroxy groups attached to C-6 and C-19 in $\mathbf{1 1}$ were converted to a $6 \beta, 19$-oxide ring in 9. The position of the oxide group at $\mathrm{C}-6 / \mathrm{C}-19$ was confirmed by the HMBC correlation (Figure 3) from H-6 to C-19.

Preliminary cytotoxicity screening revealed that $\mathbf{2}, \mathbf{5}$, and $\mathbf{6}$ exhibited significant cytotoxicty against P-388 (mouse lymphocytic leukemia) and HT-29 (human colon adenocarcinoma) cells (Table 4). The other tested compounds were not cytotoxic to P-388 and HT-29 cells. The results of further biological activity screening will be reported elsewhere in the future.

\section{Experimental Section}

General Experimental Procedures. Optical rotations were determined on a JASCO P1020 polarimeter. UV spectra were obtained on a Hitachi U-3210 spectrophotometer, and IR spectra were recorded on a JASCO FT/IR-4100 spectrophotometer. The NMR spectra were recorded on a Bruker Avance $300 \mathrm{NMR}$ spectrometer at $300 \mathrm{MHz}$ for ${ }^{1} \mathrm{H}$ and $75 \mathrm{MHz}$ for ${ }^{13} \mathrm{C}$ or on a Varian Unity INOVA 500 FT-NMR at $500 \mathrm{MHz}$ for ${ }^{1} \mathrm{H}$ and $125 \mathrm{MHz}$ for ${ }^{13} \mathrm{C}$, respectively, using TMS as internal standard. Chemical shifts are given in $\delta$ (ppm) and coupling constants in Hz. ESIMS were recorded by ESI FT-MS on a Bruker
Table 4. Cytotoxicity $^{a}$ of Compounds 1-9

\begin{tabular}{ccc}
\hline & \multicolumn{2}{c}{ cell lines $\mathrm{ED}_{50}(\mu \mathrm{g} / \mathrm{mL})$} \\
\cline { 2 - 3 } compound & HT-29 & $\mathrm{P}-388$ \\
\hline $\mathbf{1}$ & $>10$ & $>10$ \\
$\mathbf{2}$ & 0.4 & 0.2 \\
$\mathbf{3}$ & $>10$ & $>10$ \\
$\mathbf{4}$ & $>10$ & $>10$ \\
$\mathbf{5}$ & 0.5 & 0.3 \\
$\mathbf{6}$ & 3.2 & 2.8 \\
$\mathbf{7}$ & $>10$ & $>10$ \\
$\mathbf{8}$ & $>10$ & $>10$ \\
$\mathbf{9}$ & $>10$ & $>10$
\end{tabular}

\footnotetext{
${ }^{a}$ For significant activity of pure compounds, an $\mathrm{ED}_{50}$ of $\leq 4.0 \mu \mathrm{g} / \mathrm{mL}$
} is required.

APEX II mass spectrometer. Si gel 60 (Merck, 230-400 mesh) was used for column chromatography; precoated Si gel plates (Merck, Kieselgel $60 \mathrm{~F}_{254}, 0.25 \mathrm{~mm}$ ) were used for TLC analysis.

Animal Material. The soft coral $N$. erecta was collected by hand using scuba at Green Island located on the southeast coast of Taiwan, in July 2005, at a depth of $10 \mathrm{~m}$, and was stored in a freezer for 5 weeks until extraction. A voucher specimen (GN-80) was deposited in the Department of Marine Biotechnology and Resources, National Sun Yat-sen University.

Extraction and Isolation. A specimen of $N$. erecta was extracted sequentially with acetone and $\mathrm{MeOH}$. After removal of solvent in vacuo, the acetone-soluble residue was partitioned between $\mathrm{H}_{2} \mathrm{O}$ and EtOAc. 
The dried EtOAc extract (35.0 g) was chromatographed over a $\mathrm{Si}$ column using $n$-hexane, $n$-hexane/EtOAc, and EtOAc/MeOH mixtures of increasing polarity. Elution with $n$-hexane gave fractions containing compound 6, that with $n$-hexane/EtOAc (90:10) gave fractions containing compounds $\mathbf{4}$ and $\mathbf{5}$, that with $n$-hexane/EtOAc (85:15) gave fractions containing compound 3, that with EtOAc/MeOH (20:1) gave fractions containing compound 10, and that with EtOAc/MeOH (10:1) gave fractions containing compound 11. Compound $\mathbf{6}(3 \mathrm{mg})$ was further purified by HPLC (Si) by eluting with $n$-hexane. Compounds 4 $(2 \mathrm{mg})$ and $5(5 \mathrm{mg})$ were further purified by HPLC (Si) by eluting with $n$-hexane/EtOAc (90:10) and $n$-hexane/ $\mathrm{CH}_{2} \mathrm{Cl}_{2}$ (50:50), respectively. Compound $3(2 \mathrm{mg}$ ) was purified by repeated HPLC (Si) by eluting with $n$-hexane/EtOAc $(85: 15)$. Compound $\mathbf{1 0}(7.0 \mathrm{mg})$ was further purified by RP-HPLC by eluting with $\mathrm{MeOH} / \mathrm{H}_{2} \mathrm{O}(85: 15)$. Compound $11(5.0 \mathrm{mg})$ was further purified by RP-HPLC by eluting with $\mathrm{MeOH} / \mathrm{H}_{2} \mathrm{O}$ (85:15).

Compound $\mathbf{1 0}$ was fully transformed into compound $\mathbf{7}$ during NMR experiments in $\mathrm{CDCl}_{3}$. Compound 7 was then converted to a mixture containing compounds $\mathbf{7}$ and $\mathbf{8}$. Compound $\mathbf{8}(2 \mathrm{mg})$ was further purified by RP-18 HPLC by eluting with $\mathrm{MeOH} / \mathrm{H}_{2} \mathrm{O}$ (90:10). Under the same conditions, compound $\mathbf{1 1}$ was transformed into a mixture containing compounds $\mathbf{1 1}$ and $\mathbf{9}$ in $\mathrm{CDCl}_{3}$ in 7 days. Compound 9 ( $2 \mathrm{mg}$ ) was further purified by RP-18 HPLC by eluting with $\mathrm{MeOH} / \mathrm{H}_{2} \mathrm{O}(85: 15)$.

The $\mathrm{MeOH}$-soluble residue $\left(320 \mathrm{mg}\right.$ ) was partitioned between $\mathrm{H}_{2} \mathrm{O}$ and EtOAc. The dried EtOAc layer was then subjected to column chromatography on silica gel using $\mathrm{CH}_{2} \mathrm{Cl}_{2}$ and $\mathrm{CH}_{2} \mathrm{Cl}_{2} / \mathrm{MeOH}$ mixtures of increasing polarity. Elution with $\mathrm{CH}_{2} \mathrm{Cl}_{2} / \mathrm{MeOH}$ (80:1) gave fractions containing compounds $\mathbf{1}$ and $\mathbf{2}$. Compounds $\mathbf{1}(7 \mathrm{mg})$ and $\mathbf{2}(5 \mathrm{mg})$ were purified by RP-HPLC by eluting with $\mathrm{MeOH} / \mathrm{H}_{2} \mathrm{O}(60: 40)$.

$\mathbf{5 \beta , 8 \beta} \boldsymbol{\beta}$-Epidioxy-11-hydroxy-6-eudesmene (1): colorless, viscous oil; $[\alpha]^{23} \mathrm{D}+10\left(c 0.7, \mathrm{CH}_{2} \mathrm{Cl}_{2}\right)$; IR ( $\left.\mathrm{KBr}\right) v_{\max } 3322,2947,1640,1457$, 1384, 1239, 1040, 927, $739 \mathrm{~cm}^{-1}$; ${ }^{1} \mathrm{H}$ NMR and ${ }^{13} \mathrm{C}$ NMR data, see Table 1; ESIMS m/z $275[\mathrm{M}+\mathrm{Na}]^{+}$; HRESIMS $m / z$ 275.1625 [M + $\mathrm{Na}]^{+}$(calcd for $\mathrm{C}_{15} \mathrm{H}_{24} \mathrm{O}_{3} \mathrm{Na}, 275.1623$ ).

$\mathbf{5 \beta , 8} \boldsymbol{\beta}$-Epidioxy-11-hydroperoxy-6-eudesmene (2): colorless, viscous oil; $[\alpha]^{23}{ }_{\mathrm{D}}+4\left(c 0.5, \mathrm{CH}_{2} \mathrm{Cl}_{2}\right)$; IR $(\mathrm{KBr}) v_{\max } 3318,2952,1640$, 1536, 1458, 1385, 1239, 1036, 927, $734 \mathrm{~cm}^{-1} ;{ }^{1} \mathrm{H}$ NMR and ${ }^{13} \mathrm{C}$ NMR data, see Table 1; ESIMS m/z, $291[\mathrm{M}+\mathrm{Na}]^{+}$; HRESIMS m/z, 291.1573 $[\mathrm{M}+\mathrm{Na}]^{+}$(calcd for $\mathrm{C}_{15} \mathrm{H}_{24} \mathrm{O}_{4} \mathrm{Na}, 291.1572$ ).

$\left(3 R^{*}, 4 S^{*}, 5 R^{*}, 7 R^{*}, 10 R^{*}\right)-3,4-\mathrm{Epoxy}-11$-hydroxy-1-pseudoguaiene (3): colorless, viscous oil; $[\alpha]^{23} \mathrm{D}+13\left(c 0.3, \mathrm{CH}_{2} \mathrm{Cl}_{2}\right)$; IR (KBr) $v_{\max } 3321,2948,1645,1536,1463,1384,1239,1041,931,734$ $\mathrm{cm}^{-1} ;{ }^{1} \mathrm{H}$ NMR and ${ }^{13} \mathrm{C}$ NMR data, see Table 1; ESIMS $\mathrm{m} / z 259$ [M $+\mathrm{Na}]^{+}$; HRESIMS $m / z$ 259.1676 $[\mathrm{M}+\mathrm{Na}]^{+}$(calcd for $\mathrm{C}_{15} \mathrm{H}_{24} \mathrm{O}_{2} \mathrm{Na}$, 259.1674).

8及-Hydroxyprespatane (4): colorless, viscous oil; $[\alpha]^{23} \mathrm{D}+9(c$ $0.4, \mathrm{CHCl}_{3}$ ); IR (KBr) $v_{\max } 3307,2947,1640,1457,1384,1239,1035$, 931, $738 \mathrm{~cm}^{-1}$; ${ }^{1} \mathrm{H}$ NMR and ${ }^{13} \mathrm{C}$ NMR data, see Table 2; ESIMS $\mathrm{m} / \mathrm{z}$ $243\left[\mathrm{M}+\mathrm{Na}^{+}\right.$; HRESIMS $\mathrm{m} / z$ 243.1726 $[\mathrm{M}+\mathrm{Na}]^{+}$(calcd for $\mathrm{C}_{15} \mathrm{H}_{24} \mathrm{ONa}$, 243.1725).

$\boldsymbol{8} \boldsymbol{\beta}$-Hydroperoxyprespatane (5): colorless, viscous oil; $[\alpha]^{23}{ }_{\mathrm{D}}+8$ (c $0.2, \mathrm{CHCl}_{3}$ ); IR (KBr) $v_{\max } 3384,2951,1640,1459,1442,1374$, 1252, 1129, 1048, 945, $892 \mathrm{~cm}^{-1}$; ${ }^{1} \mathrm{H}$ NMR and ${ }^{13} \mathrm{C}$ NMR data, see Table 2; ESIMS m/z $433[\mathrm{M}+\mathrm{Na}]^{+}$; HRESIMS m/z $259.1675[\mathrm{M}+$ $\mathrm{Na}]^{+}$(calcd for $\mathrm{C}_{15} \mathrm{H}_{24} \mathrm{O}_{2} \mathrm{Na}, 259.1674$ ).

24-Methylenecholesta-2,4,6-trien-19-ol (7): colorless, viscous oil; $[\alpha]^{23}{ }_{\mathrm{D}}+43\left(c 0.7, \mathrm{CHCl}_{3}\right) ; \mathrm{UV}\left(\mathrm{CHCl}_{3}\right) \lambda_{\max }(\log \varepsilon) 247$ (3.97), 279 (3.18); IR (KBr) $v_{\max } 3385,2958,1645,1463,1374,1051,884,734$ $\mathrm{cm} ;{ }^{1} \mathrm{H}$ NMR and ${ }^{13} \mathrm{C}$ NMR data, see Table 3; EIMS $\mathrm{m} / \mathrm{z} 394[\mathrm{M}]^{+}$; HREIMS $m / z, 394.3230[\mathrm{M}]^{+}$(calcd for $\mathrm{C}_{28} \mathrm{H}_{42} \mathrm{O}, 394.3235$ ).

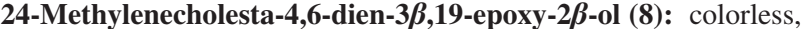
viscous oil; $[\alpha]^{23}{ }_{\mathrm{D}}+166\left(c \mathrm{c} 2, \mathrm{CHCl}_{3}\right) ; \mathrm{UV}(\mathrm{MeOH}) \lambda_{\max }(\log \varepsilon) 240$ (3.63); IR (KBr) $v_{\max } 3406,2932,1640,1463,1374,1265,1040,884$, $749 \mathrm{~cm}^{-1}$; ${ }^{1} \mathrm{H}$ NMR and ${ }^{13} \mathrm{C}$ NMR data, see Table 3; ESIMS $\mathrm{m} / \mathrm{z}, 433$ $[\mathrm{M}+\mathrm{Na}]^{+}$; HRESIMS $\mathrm{m} / z$ 433.3084 $[\mathrm{M}+\mathrm{Na}]^{+}$(calcd for $\mathrm{C}_{28} \mathrm{H}_{42} \mathrm{O}_{2} \mathrm{Na}$, 433.3082).

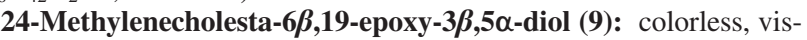
cous oil; $[\alpha]^{23} \mathrm{D}+176\left(c 0.2, \mathrm{CHCl}_{3}\right)$; IR (KBr) $v_{\max } 3396,2963,1462$, 1380, 1259, 1098, 1030, 858, $795 \mathrm{~cm}^{-1} ;{ }^{1} \mathrm{H}$ NMR and ${ }^{13} \mathrm{C}$ NMR data, see Table 3; ESIMS $m / z 453\left[\mathrm{M}+\mathrm{Na}^{+}\right.$; HRESIMS $m / z 453.3343$ [M $+\mathrm{Na}]^{+}$(calcd. for $\mathrm{C}_{28} \mathrm{H}_{46} \mathrm{O}_{3} \mathrm{Na}, 453.3344$ ).

Cytotoxicity Testing. Cytotoxicity was determined against P-388 (mouse lymphocytic leukemia) and HT-29 (human colon adenocarcinoma) tumor cells using the MTT assay method. The experimental details of this assay were carried out according to a previously described procedure. $^{18}$

Acknowledgment. We thank J. M. Pezzuto, formerly of the Department of Medicinal Chemistry and Pharmacognosy, University of Illinois at Chicago, for the provision of the P-388 cell line. The HT-29 cell line was purchased from the American Type Culture Collection. This work was supported by grants from the National Science Council and Ministry of Education (95C030311) of the Republic of China awarded to C.-Y.D.

\section{References and Notes}

(1) Blunt, J. W.; Copp, B. R.; Munro, M. H. G.; Northcote, P. T.; Prinsep, M. R. Nat. Prod. Rep. 2006, 23, 26-78, and literature cited in previous reviews.

(2) Coll, J. C.; Bowden, B. F.; Tapiolas, D. M.; Willis, R. H. Tetrahedron 1985, 41, 1085-1092.

(3) Kitagawa, I.; Cui, Z.; Son, B. W.; Kobayashi, M.; Kyogoku, Y. Chem. Pharm. Bull. 1987, 35, 124-135.

(4) Handayani, D.; Edrada, R. A.; Proksch, P.; Wray, V.; Witte, L. J. Nat. Prod. 1997, 60, 716-718.

(5) Duh, C.-Y.; Wang, S.-K.; Weng, Y.-L. Tetrahedron Lett. 2000, 41, $1401-1404$

(6) Duh, C.-Y.; Wang, S.-K.; Weng, Y.-L.; Chiang, M.-Y.; Dai, C.-F. J. Nat. Prod. 1999, 62, 1518-1521.

(7) Rao, M. R.; Venkatesham, U.; Venkateswarlu, Y J. Nat. Prod. 1999, 62, 1584-1585.

(8) El-Gamal, A. A. H.; Wang, S.-K.; Dai, C.-F.; Duh, C.-Y. J. Nat. Prod. 2004, 67, 1455-1458.

(9) Duh, C.-Y.; Wang, S.-K.; Chu, M.-J.; Sheu, J.-H. J. Nat. Prod. 1998, $61,1022-1024$

(10) König, G. M.; Wright, A. D. J. Org. Chem. 1997, 62, 3837-3840.

(11) Warners, U.; Wihstutz, K.; Bülow, N.; Fricke, C.; König, W. A. Phytochemistry 1998, 49, 1723-1731.

(12) Bortolotto, M.; Braeckman, J. C.; Daloze, D.; Losman, D.; Tursch, B. Steroids 1976, 28, 461-466.

(13) Wang, G.; Li, F.; Zeng, L.; Ma, L.; Tu, G. Chem. J. Chin. Univ. 1992, $13,623-627$.

(14) Nagashima, F.; Murakami, M.; Takaoka, S.; Asakawa, Y. Chem. Pharm. Bull. 2004, 52, 949-952.

(15) Fischer, N. H.; Oliver, E. J.; Fischer, H. D. Prog. Chem. Org. Nat. Prod. 1979, 38, 47-390.

(16) Barrero, A. F.; Quilez del Moral, J. F.; Herrador, M. M.; Akssira, M.; Bennamara, A.; Akkad, S.; Aitigri, M. Phytochemistry 2004, 65, 25072516.

(17) Masuyama, A.; Sugawara, T.; Nojima, M.; McCullough, K. J. Tetrahedron 2003, 59, 353-366.

(18) Hou, R.-S.; Duh, C.-Y.; Chiang, M. Y.; Lin, C.-N. J. Nat. Prod. 1995, 58, 1126-1130.

NP070189T 